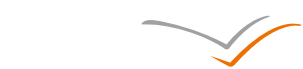

VERSITA
GEOCHRONOMETRIA 35 (2010), pp 1-2

DOI $10.2478 / \mathrm{v} 10003-010-0012-6$

Available online at

versita.metapress.com and www.geochronometria.pl

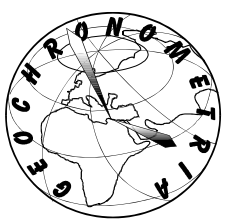

\title{
ALGIRDAS GAIGALAS (1933 -2009)
}

\author{
by STANISLAW FEDOROWICZ ${ }^{1}$ \\ ${ }^{I}$ Department of Geomorphology and Quaternary Geology, Gdansk University
}

Abstract: Obituary of Professor Algirdas Gaigalas.

Keywords: Obituary, Gaigalas

Algirdas Gaigalas was born on February 27, 1933. Between 1952 and 1957, he studied geology at the Vilnius University. After graduation, he worked at the Institute of Geology and Geography, Vilnius University and at the department of the Lithuanian Academy of Sciences, Vilnius Pedagogical University. At the Vilnius University he was delivering, among others, lectures on Quaternary geology, geomorphology and petrography. In 1962 he received his Ph.D and in 1977 his habilitation. Professor Gaigalas promoted 9 doctors. He has published over 500 scientific articles and was the author of 12 monographs. He was also an honorary member of INQUA, a member of the Russian Academy of Sciences, President of Lithuanian Academy of Sciences, a member of the Lithuanian Association of Geologists, Lithuanian Geographical Society and Polish Association of Geologists. He has participated in many conferences, congresses and symposia which were held in Russia, Canada, Sweden, USA, Belgium, Holland, Germany, France, China, South Africa, Brazil. He was Editor-in-Chief of the journal Geologija and a member of editorial boards of many other journals. Professor Gaigalas died on 4 June 2009 (Baltrunas, 2009)

Professor Gaigalas visited Poland many times. For many years he led joint studies with researchers from the Museum of the Earth, Silesian University of Technology, Department of Geomorphology and Quaternary Geology at Gdansk University as well as Maria Curie-Sklodowska University in Lublin. Gdansk-Vilnius cooperation began in 2001 during and after the VII International Conference "Methods of Absolute Chronology", which took place in Ustron. First plans of cooperation were created during the train ride from Bielsko-Biala to Warsaw. Already in the summer of that year, first samples for TL dating were collected from Vilkiskes profile, Lithuania. First results of this work were presented at the "Basin Stratigraphy modern methods and problems" conference in September 2002 (Gaigalas et al., 2002). Results of chronostrati-

Corresponding author: S. Fedorowicz e-mail: geosf@univ.gda.pl

ISSN 1897-1695 (online), 1733-8387 (print) C 2010 GADAM Centre, Institute of Physics, Silesian University of Technology.

All rights reserved. graphical research of Vilkiskes profile have been published a few months later (Gaigalas and Fedorowicz, 2002; Fedorowicz, 2003). Collaboration with Professor were mainly focused on analysis of luminescent dates. Research on cesium determination in deluvial sediments were also conducted. Results and conclusions obtained from this research were presented in Geologija (Gaigalas et al., 2003).

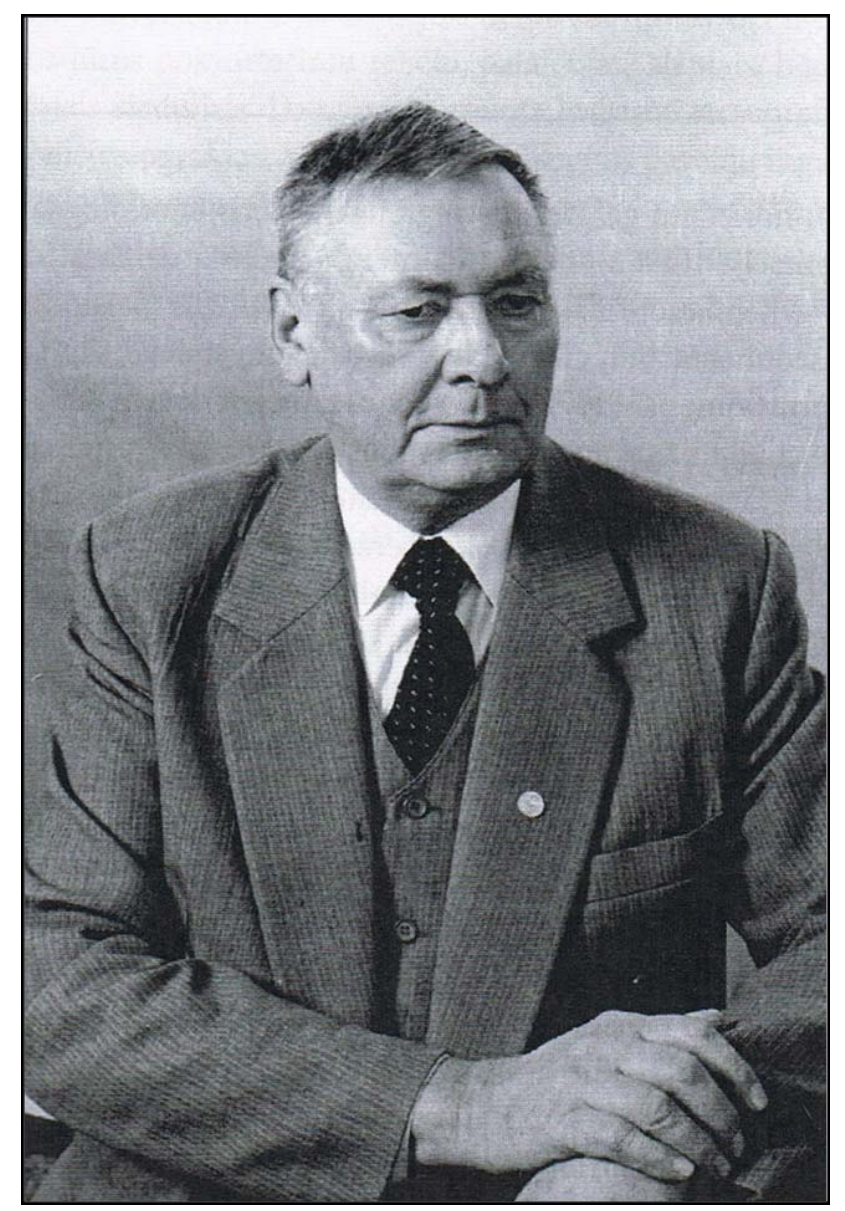

Fig. 1. Prof. Algirdas Gaigalas (Baltrunas, 2009) 


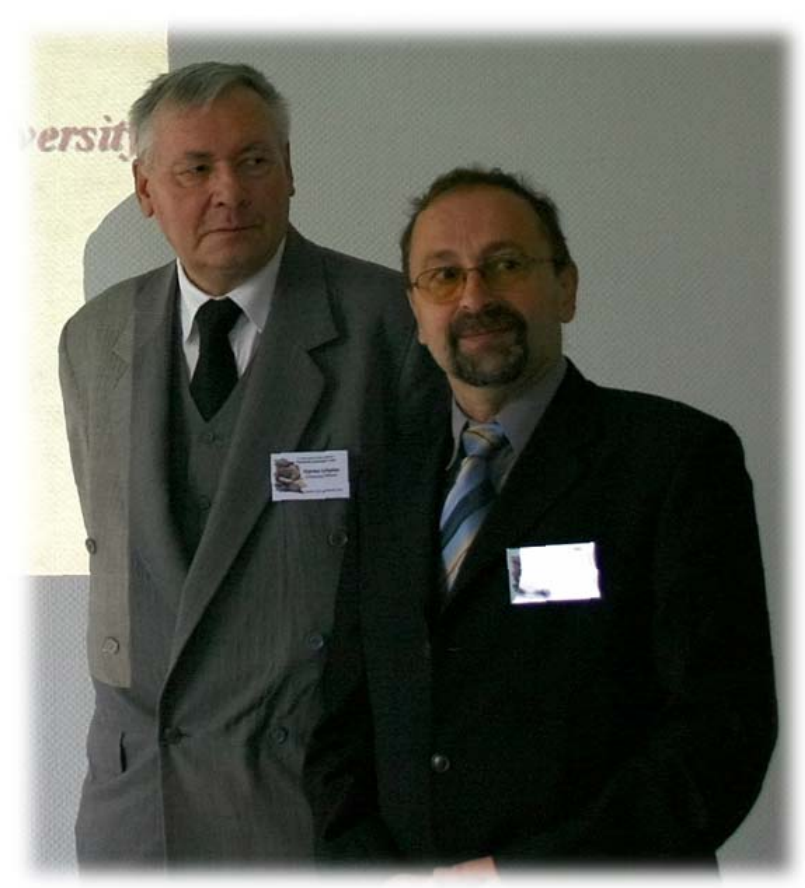

Fig. 2. Prof. Algirdas Gaigalas and prof. Stanislaw Fedorowicz at the "Dating minerals and rocks" conference, Gdansk 2006. (photo P.P. Woźniak).

In 2003-2004 the analysis of the next profile - Tartokai, was started. At the VIII International Conference on "Methods of Absolute Chronology", which was held in April 2004 in Gliwice, Gdansk and Vilnius centers marked their presence by an oral presentation (Gaigalas et al., 2004) and subsequently by publication in Geologija (Gaigalas et al., 2005). Publications included chronostratigraphical development and correlation analysis between Vilkiskes and Tartokai profiles. In October 2006, the Department of Geomorphology and Quaternary Geology, at Gdansk University was the organizer of the IX Conference "Dating minerals and rocks." One of its speeches was written by Gaigalas and Fedorowicz (Gaigalas and Fedorowicz, 2006). the presentation concerned next Lithuanian profiles: Rokai, Netiesos. Successive conferences, thematically related to radiometric methods, always involved Gaigalas and Fedorowicz duo. These authors actively participated in the IX International Conference "Methods of Absolute Chronology" (April 2007 in Ustroń) (Gaigalas and Fedorowicz, 2007) and X Conference "Dating Minerals and Rocks ", held in Lublin in October 2008 (Gaigalas and Fedorowicz, 2008). In 2008 samples were again collected from Vilkiskes and Tartokai profiles for methodical luminescent researches. Results were to be presented at the next thematic conferences in years 2009-2010.

Professor Gaigalas already did not attend a conference devoted to the 50th anniversary of the Gdansk geomorphology which took place in Gdansk in October 2009. Article in Geologija (Gaigalas and Fedorowicz, 2009) was a partial presentation of the latest research and a summary of eight years collaboration between Gdansk and Vilnius centres. Last work (Fedorowicz and Gaigalas, 2010) will be released this year in Geochronometria.
Eight years of collaboration between Gdansk and Vilnius has resulted in active participation in six conferences, six articles published in journals from the Master Journal List and one habilitation (Fedorowicz, 2006). Collaboration with Professor Gaigalas allowed the development of chronostratigraphy of Neopleistocene in Lithuania (Fedorowicz, 2006). Conclusions from the methodical research of lake sediment samples will help to modernise preparation and way of luminescent measurements of such a sediments (Gaigalas and Fedorowicz, 2006 and 2007; Fedorowicz and Gaigalas, 2010).

Professor Algirdas Gaigalas was a very modest, friendly man, with a nice and gentle disposition. He had a great sense of humor. Always ready to work and cooperate. I am extremely sorry and regret that this is already the end to our collaboration.

\section{REFERENCES}

Baltrunas V, 2009. In memoriam Professor Algirdas Gaigalas (1933 2009). Live devoted to science and education. Geologija 51(1-2): i-iii.

Fedorowicz S, 2003. Interlaboratory comparison of TL dating results on the Vilkiškes profile (Lithuania). Geologija 42: 40-44.

Fedorowicz S, 2006. Metodyczne aspekty luminescencyjnego oznaczania wieku osadów neoplejstoceńskich Europy Środkowej (Methodical aspects of Central Europe neopleistocene sediments age determinig, with use of luminescence methods). Gdańsk, Wydawnictwo Uniwersytetu Gdańskiego: $157 \mathrm{pp}$.

Fedorowicz S and Gaigalas A, 2010. Geochronological and sedimentodological interpretation of interglacial sediments based TL dating. Geochronometria 35: 75-83.

Gaigalas A, Fedorowicz S and Melesyte M, 2002. TL age of Middle and Late Pleistocene deposits of Vilkiskes exposure in Eastern Lithuania. Extended abstracts "Baltic Stratigraphical Association - Basin stratigraphy - modern methods and problems"'-22-27.IX.2002, Vilnius, Lithuania: 41-43.

Gaigalas A and Fedorowicz S, 2002. Thermoluminescence dates Mid and Late Pleistocene in exposure. Eastern Litnuania. Geologija 38: 31-40.

Gaigalas A, Fedorowicz S, Racinkas A and Bauziene J, 2003. Radioaktyvaus cezio (Cs-137 izotopo) aktyvumas deliuvio dirvożemiuose Ryt Lietuvos Aukstumose (Activity of Cs-137 izotope in deluvial soils of East Lithuanian Uplands). Geologija 42: 26-32.

Gaigalas A, Fedorowicz S and Melesyte M, 2004. New TL dates of aquatic sandy sediments of Middle-Upper Pleistocene in Lithuania. Book of abstract 8th International Conference "Methods of absolute chronology”, 17 -19 May 2004, Ustroń: 48-50.

Gaigalas A and Fedorowicz S, 2006. Dosimetric age (TL, OSL) of aquatic sandy sediments of Middle - Upper Pleistocene in Lithuania. Materiaty konferencyjne „Datowanie mineratów i skat”, Gdańsk, 23 -24 października 2006: 33 -36.

Gaigalas A, Fedorowicz S and Melesyte M, 2005. TL dates of aquatic sandy sediments of Middle- Upper Pleistocene in Lithuania. Geologija 51: 39-50.

Gaigalas A and Fedorowicz S, 2007. Sedimentological interpretation thermolimnescence (TL) ages of Pleistocene aquatic sediments to fallow Lithuanian example. Abstracts \& Programme 9th International Conference "Methods of absolute chronology": 67

Gaigalas A and Fedorowicz S, 2008. Interpretacja danych sedymentologicznych i dat termoluminescencyjnych (TL) interglacjalnych osadów wodnych na przykładzie Tartokai na Litwie. Materiały $X$ ogólnopolskiej sesji naukowej „Datowanie minerałów i skat”, UMCS, Lublin, 23-24 X. 2008: 20-26.

Gaigalas A and Fedorowicz S, 2009. Co- cooperation between Gdańsk and Vilnius universities in pleistocene geochronology investigation. Geologija 51(3-4) (67-68): 76-87, DOI: 10.2478/v10056-0090009-x. 